\title{
EFFECT OF THE GMAW METAL-TRANSFER MODE ON THE WELD-METAL STRUCTURE OF HSLA X80
}

\author{
VPLIV NAČINA PRENOSA KOVINE PRI OBLOČNEM VARJENJU \\ V ZAŠČITNEM PLINU (GMAW) NA STRUKTURO ZVARA NA \\ JEKLU HSLA X80
}

\author{
Maja Jurica, Zoran Kožuh, Branko Bauer, Ivica Garašić \\ University of Zagreb, Faculty of Mechanical Engineering and Naval Architecture, Ivana Lucica 5, 10002 Zagreb, Croatia \\ branko.bauer@fsb.hr \\ Prejem rokopisa - received: 2016-04-01; sprejem za objavo - accepted for publication: 2016-06-22
}

doi:10.17222/mit.2016.057

\begin{abstract}
This paper presents the influence of the metal-transfer mode during GMAW of 10-mm-thick HSLA steel grade X80 on the inclusions and acicular ferrite content in the weld metal. Welding of butt joint specimens was carried out by the conventional short-circuit and CBT metal-transfer mode with different shielding gases and wire feed speeds. An analysis of obtained results showed that the metal-transfer mode affects the weld-metal structure by influencing the acicular ferrite content in relation to the number and size of the inclusions found in the weld metal.

Keywords: GMAW CBT welding, non-metallic inclusions, acicular ferrite, HSLA X80
\end{abstract}

Članek predstavlja vpliv načina prenosa kovine med obločnim varjenjem v zaščitnem plinu (GMAW), 10 mm debelega visokotrdnostnega malolegiranega (HSLA) jekla vrste X80 na vključke in vsebnost acikularnega ferita v zvaru. Varjenje soležnih vzorcev je bilo izvedeno z običajnim kratkostičnim načinom in s kontroliranim prenosom kovine (CBT) z različnimi zaščitnimi plini in hitrostmi podajanja žice. Analiza dobljenih rezultatov je pokazala, da način prenosa kovine vpliva na strukturo zvara, z vplivanjem na vsebnost acikularnega ferita v povezavi s številom in velikostjo vključkov v kovini zvara.

Ključne besede: GMAW CBT varjenje, nekovinski vključki, acikularni ferit, HSLA X80

\section{INTRODUCTION}

The HSLA steel grade X80 is more and more in use, but not so much has been investigated on the subject of the influence of the metal transfer on the structure of the weld metal. The most commonly used technology for joining pipeline steels is GMAW, because it results in high productivity and efficiency and also because by changing the welding parameters the metal-transfer mode can easily be modified to achieve different heat inputs. When GMAW with a short-circuit metal-transfer mode is used, the occurrence of spatter is observed. Spatter generates mostly when re-arcing takes place immediately after the short circuit causing additional financial expenses. In order to eliminate spatter, the critical time period, where the molten metal is squeezed by the pinch force effect, the voltage just before re-arcing must be accurately sensed. ${ }^{1}$ Following this, the welding current is rapidly decreased immediately after the re-arcing occurs. This causes the molten metal at the tip of the wire to be transferred to the weld pool using only the surface tension, resulting in minimization or even elimination of the spatter generation., ${ }^{2,3}$ The modified metal transfer also affects the mechanical properties of the weld metal, which directly depend on the microstructure. ${ }^{4}$ Micro-alloyed low-carbon steels with a multiphase microstructure can have a high tensile strength, good toughness and weldability. This combination of properties has led to their application in the manufacturing of large-diameter pipes for gas and oil transportation with significant reductions of wall thickness. Interest in acicular ferrite (AF) formation is motivated by recent evidence that pipeline steels with bainitic microstructure having predominantly AF+MA (martensite-austenite) microstructures that have superior combinations of tensile strength and toughness compared with $\mathrm{CB}$ (conventional bainite) + MA microstructures. ${ }^{5}$ Acicular ferrite is one of the microstructural constituents that is most commonly observed in the weld deposit of low-alloy steel and is easily differentiated from other constituents by its fine interlocking nature. ${ }^{6}$ As follows from Figure 1, the ferrite side plate (such as Widmanstätten ferrite or upper bainite) provides preferential crack-propagation paths in austenite grains. This is because the ferrite side plates nucleate at grain boundaries as parallel plates with the same crystallographic orientation. Therefore, the toughness of the steels decreases with an increasing amount of these structures. Alternatively, the acicular ferrite laths nucleate intragranularly at the surface of the inclusions. Then, they have a chaotic crystallographic orientation, resulting in a retardation of the propagation path for a cleavage crack in the metal. Therefore, it can be expected that the steel toughness 
increases with an increasing amount of acicular ferrite in the steel. ${ }^{7}$

From the published literature on acicular ferrite in weld metals it is well established that non-metallic inclusions present effective nucleation sites for acicular ferrite and a variety of mechanisms were proposed. Therefore, various authors have discussed the effect of different factors such as: cooling rate in the temperature range $800{ }^{\circ} \mathrm{C}$ to $500{ }^{\circ} \mathrm{C}$, chemical composition of the steel, size of the austenite grains, and inclusion parameters on the formation of intragranular acicular ferrite in the weld metal. ${ }^{5,7-10}$ However, in real practice it is very difficult, if not impossible, to determine the influence of each of the previously mentioned factors separately.

In the present work, the effect of the metal-transfer mode during GMAW on the formation of non-metallic inclusions as well as acicular ferrite in HSLA X80 steel has been investigated.

\section{EXPERIMENTAL PART}

The base material used in the experiment was highstrength, low-alloy steel API 5L X80 and the filler material was G $624 \mathrm{M} \mathrm{Mn3NiCrMo} \mathrm{(according} \mathrm{to} \mathrm{EN}$ ISO 16834) wire, $1.2 \mathrm{~mm}$ in diameter. The exact che-

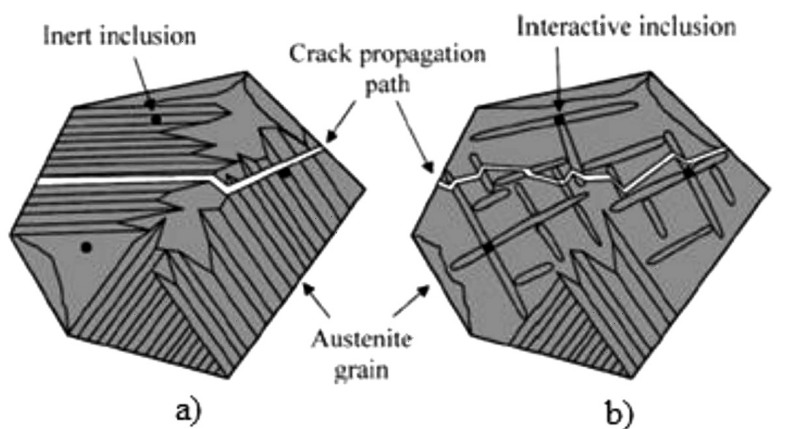

Figure 1: Schematic illustration of propagation path: a) in predominantly ferrite side plate and b) acicular ferrite microstructure ${ }^{7}$ Slika 1: Shematski prikaz poti napredovanja razpoke: a) v pretežno feritni plošči in b) v mikrostrukturi acikularnega ferita ${ }^{7}$

Table 1: Chemical composition of base and filler materials ${ }^{11}$ Tabela 1: Kemijska sestava osnovnega materiala in dodanega materiala $^{11}$

\begin{tabular}{|c|c|c|c|}
\hline \multirow{4}{*}{ Material } & API 5L X80 & \multicolumn{2}{|c|}{$\begin{array}{c}\text { G 62 4 M Mn3NiCrMo } \\
\text { (according to EN ISO 16834) }\end{array}$} \\
\hline \multirow{4}{*}{$\begin{array}{c}\text { Chemical } \\
\text { composition in } \\
\text { mass fractions, } \\
\text { (w/\%) }\end{array}$} & $\mathrm{C}$ & 0.07 & 0.10 \\
\cline { 2 - 4 } & $\mathrm{Si}$ & 0.35 & 0.75 \\
\cline { 2 - 4 } & $\mathrm{Mn}$ & 1.94 & 1.65 \\
\cline { 2 - 4 } & $\mathrm{P}$ & 0.015 & - \\
\cline { 2 - 4 } & $\mathrm{S}$ & 0.0 & - \\
\cline { 2 - 4 } & $\mathrm{Ni}$ & 0.15 & 0.60 \\
\cline { 2 - 4 } & $\mathrm{Mo}$ & 0.001 & 0.30 \\
\cline { 2 - 4 } & $\mathrm{Cu}$ & 0.01 & 0.08 \\
\hline
\end{tabular}

mical composition of the base and the filler material used in this experiment is shown in Table $\mathbf{1}$.

Gas metal arc welding of the specimens was carried out using two different metal-transfer modes: shortcircuit (SC) mode and controlled bridge transfer (CBT). During the experiment, three different wire feed speeds were used $(4 \mathrm{~m} / \mathrm{min}, 5.5 \mathrm{~m} / \mathrm{min}$ and $7 \mathrm{~m} / \mathrm{min})$.

The maximum wire feed speed was determined by previous experiments as the upper limit where the controlled bridge transfer mode is still stable. Also, the minimum value of the wire feed speed is defined as the speed that does not result in a lack of fusion. The shielding gases used were M21 and C1 according to EN ISO 14175: 2008 standard and a special mixture consisting of $59 \% \mathrm{CO}_{2}$ and $41 \% \mathrm{Ar}$ with the flow set at $18 \mathrm{~L} / \mathrm{min}$. The contact tip to work distance (CTWD) was $12 \mathrm{~mm}$, while the welding speed was $25 \mathrm{~cm} / \mathrm{min}$. Welding of the filler passes was carried out using the neutral technique. The interpass temperature was controlled with the infrared thermometer to be under $100{ }^{\circ} \mathrm{C}$. Because of a very narrow span of welding parameters which result in good quality root pass (wire feed speed $-3.5 \mathrm{~m} / \mathrm{min}$, welding speed $-11.6 \mathrm{~cm} / \mathrm{min}$, shielding gas flow -16 L/min, CTWD - $15 \mathrm{~mm}$, pull technique, short circuit metal transfer mode, heat input $-8.4 \mathrm{~kJ} / \mathrm{cm}$ ), all of the root passes of the specimens were robotically (Almega OTC AX-V6 robot and Varstroj VPS 400 welding power source) welded with the same parameters. Filler passes were welded using the Daihen Varstroj Welbee P500L welding power source and BUG-O Systems MDS 1002 drive system. Sample designations and varied welding parameters are shown in Table 2.

Table 2: Sample designation and varied welding parameters Tabela 2: Oznaka vzorcev in različni parametri varjenja

\begin{tabular}{|c|c|c|c|}
\hline $\begin{array}{c}\text { Sample } \\
\text { nr. }\end{array}$ & $\begin{array}{c}\text { Shielding gas } \mathrm{CO}_{2} \\
\text { content, in volume } \\
\text { fractions }(X / \%)\end{array}$ & $\begin{array}{c}\text { Metal transfer } \\
\text { mode, } \\
\text { CV/CBT }\end{array}$ & $\begin{array}{c}\text { Wire feed } \\
\text { speed, } \\
\text { m/min }\end{array}$ \\
\hline 1 & 18 & CV & 4 \\
\hline 2 & 18 & CBT & 4 \\
\hline 3 & 18 & CV & 5.5 \\
\hline 4 & 18 & CBT & 5.5 \\
\hline 5 & 18 & CV & 7 \\
\hline 6 & 18 & CBT & 7 \\
\hline 7 & 59 & CV & 4 \\
\hline 8 & 59 & CBT & 4 \\
\hline 9 & 59 & CV & 5.5 \\
\hline 10 & 59 & CV & 5.5 \\
\hline 11 & 59 & CV & 5.5 \\
\hline 12 & 59 & CBT & 5.5 \\
\hline 13 & 59 & CBT & 5.5 \\
\hline 14 & 59 & CVT & 5.5 \\
\hline 15 & 59 & CBT & 7 \\
\hline 16 & 59 & CV & 7 \\
\hline 17 & 100 & CBT & 4 \\
\hline 18 & 100 & CV & 5.5 \\
\hline 19 & 100 & CBT & 5.5 \\
\hline 20 & 100 & & 7 \\
\hline 21 & 100 & 100 & 7 \\
\hline 22 & & & \\
\hline & 10 & & 4 \\
\hline
\end{tabular}


After welding of the plates, test specimens were prepared in accordance with the EN ISO 15614-1 standard. Later on, specimens were polished and etched in $3 \%$ Nital solution for micrographic analysis and in $7 \%$ Nital solution for macrograph analysis. The exact chemical composition of the inclusions found in the weld metal was analysed by SEM TESCAN VEGA 5136 MM equipped with Oxford EDS detector. Microstructural analysis of the weld metal was observed with an Olympus GX51F-5 inverted light microscope.

All of the gathered data on the microstructure of the weld metal (acicular ferrite content) were statistically analysed with the Design Expert software program. A face-centered central composite design with three factors was used to analyse the influence of the varied factors. In this design the star points (not centered) are at the center of each face of the factorial space, so $\alpha= \pm 1$. Center points were repeated 3 times in order to define the "Pure error" and the curvature of the response surface. According to ANOVA of the results of weld-metal microstructure, categorical factor metal transfer mode (conventional-CV and CBT) is a significant factor with P-value $<0.0001$. In order to analyse in detail the influence of the metal-transfer mode as the significant factor, only the results for one shielding gas $(\mathrm{C} 1)$ are presented and analysed. The reason for analysing this specific shielding gas lies in the fact that it promotes non-axial detachment of the metal droplet, causing more spatter. ${ }^{11-14}$ Because the newly developed CBT metal-transfer mode can reduce or even eliminate spatter generation, regardless of the type of shielding gas, $100 \% \mathrm{CO}_{2}$ shielding gas could be used in short circuit and globular metal transfer parameter range. This type of shielding gas is not typically used when welding HSLA X80, so a detailed analysis of its effect on the weld-metal properties needs to be investigated.

\section{RESULTS}

\subsection{Chemical composition and size distribution of non-metallic inclusions in the weld metal}

Inclusions of varying size and type were examined and the results in Table $\mathbf{3}$ present the average values of all the inclusions analysed per one test specimen. The results indicate that the analysed inclusions are rich in oxygen, silicon, manganese and aluminium with a small amount in titanium and sulphur. The smallest inclusions were observed in sample 17 , which was welded with a wire feed speed of $4 \mathrm{~m} / \mathrm{min}$ and a short-circuit metaltransfer mode. The chemical compositions of these inclusions are in relation to the diameter - it can be seen that the mass percentage of all the chemical elements are at the lowest values in comparison to the other inclusions. It can also be noticed that in the samples 17 and 18 no titanium was observed. In samples 19 and 21 , which were welded with higher wire feed speeds (5.5 $\mathrm{m} / \mathrm{min}$ and $7 \mathrm{~m} / \mathrm{min}$ ) and short-circuit mode, no chromium was found. All the other alloying elements are noticed to be in a positive linear dependence with the diameter of the observed inclusions (with the growth of the inclusions also the growth of the mass percentage of all the elements is observed). Taking into account the fact that carbon, iron and chromium are constituent elements of the base and filler metal, the observed inclusion can be characterized as complex $\mathrm{Si}$-, $\mathrm{Mn}$ - and $\mathrm{Al}$-oxides.

The average values of the size distribution of the observed non-metallic inclusions are also presented in Table 3. It can be seen that the average diameter of the inclusions varied in the range from $0.51 \mu \mathrm{m}$ to $1.12 \mu \mathrm{m}$. The smallest inclusions are noticed in sample 1 (welded with $4 \mathrm{~m} / \mathrm{min}$ wire feed speed and short-circuit, metaltransfer mode) and the largest inclusions are observed in sample 19 (welded with $5.5 \mathrm{~m} / \mathrm{min}$ wire feed speed and short-circuit transfer mode), as can be seen in Figure 2. Comparing the chemical composition with the size distribution of the observed inclusions it can be seen that the diameter of inclusions containing chromium is smaller when welding with the short-circuit metal-transfer mode (compared to the CBT metal-transfer mode) and larger when no chromium is found. Samples welded with the globular metal-transfer mode (samples 19 and 21) show significant difference in inclusion size (increase in size is over $100 \%$ ) to the sample (Sample 17) welded with short-circuit metal-transfer mode.

\subsection{Microstructure of the weld metal}

The microstructure analysis of the weld metal is given in Table 4. The obtained results show the area fraction of acicular ferrite and also of inclusions. Minimum acicular content of $60.2 \%$ and minimum content of

Table 3: Chemical composition and size distribution of the observed inclusions (samples 17-22)

Tabela 3: Kemijska sestava in razporeditev velikosti opaženih vključkov (vzorci 17 - 22)

\begin{tabular}{|c|c|c|c|c|c|c|c|c|c|c|}
\hline \multirow{2}{*}{ Sample } & \multirow{2}{*}{$\bar{d}_{\mathrm{i}} \mu \mathrm{m}$} & \multicolumn{9}{|c|}{ Chemical composition, in mass fractions $(w / \%)$} \\
\hline & & $\mathrm{C}$ & $\mathrm{O}$ & $\mathrm{Al}$ & $\mathrm{Si}$ & $S$ & $\mathrm{Cr}$ & $\mathrm{Ti}$ & $\mathrm{Mn}$ & $\mathrm{Fe}$ \\
\hline 17 & 0.51 & 5.49 & 7.06 & 0.22 & 3.55 & 0.43 & 0.47 & - & 6.30 & 77.00 \\
\hline 18 & 0.88 & 6.80 & 10.51 & 0.33 & 4.48 & 0.71 & 0.69 & - & 6.38 & 71.25 \\
\hline 19 & 1.12 & 7.27 & 19.10 & 0.95 & 6.93 & 0.66 & - & 0.18 & 10.68 & 54.05 \\
\hline 20 & 0.93 & 7.10 & 13.61 & 0.92 & 5.96 & 0.43 & 0.48 & 0.17 & 11.48 & 60.90 \\
\hline 21 & 1.01 & 9.73 & 18.57 & 0.31 & 6.55 & 0.68 & - & 0.32 & 12.39 & 51.23 \\
\hline 22 & 0.87 & 8.50 & 12.40 & 0.34 & 5.04 & 0.61 & 0.46 & 0.22 & 11.13 & 61.48 \\
\hline
\end{tabular}




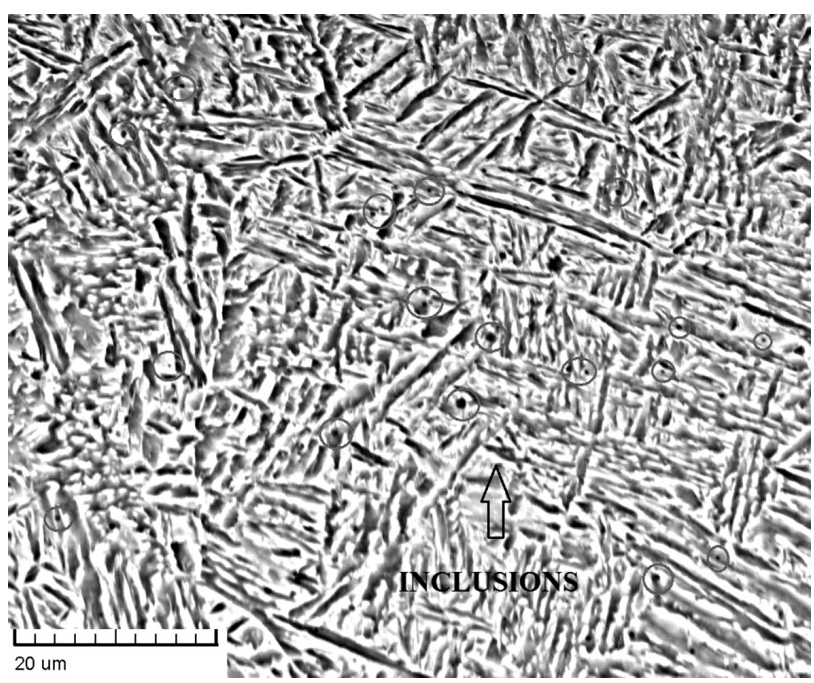

Figure 2: SEM micrograph of the sample 19

Slika 2: SEM-posnetek vzorca 19

inclusions of $1.3 \%$ is achieved in sample 18 (Figure 3), which was welded with the CBT metal-transfer mode and a wire-feed speed of $4 \mathrm{~m} / \mathrm{min}$. Also, the maximum values of the area fraction for both acicular ferrite $(74.9 \%)$ and inclusions $(2.1 \%)$ were observed in the same sample, sample 21 (which was welded with globular transfer mode and $7 \mathrm{~m} / \mathrm{min}$ wire feed speed). From these results it can be clearly seen that the area fraction of acicular ferrite is closely related to the area fraction of inclusions - higher content of inclusion results in a higher content of acicular ferrite. The biggest difference in the obtained results between the CBT and globular transfer mode is observed in samples 19 and 20. From Table 4 it can be seen that the area fraction of the acicular ferrite is in sample $1916 \%$ larger than in sample 20. Similarly, the area fraction of inclusions is in sample 19 larger by $36 \%$ than in sample 20. Comparing

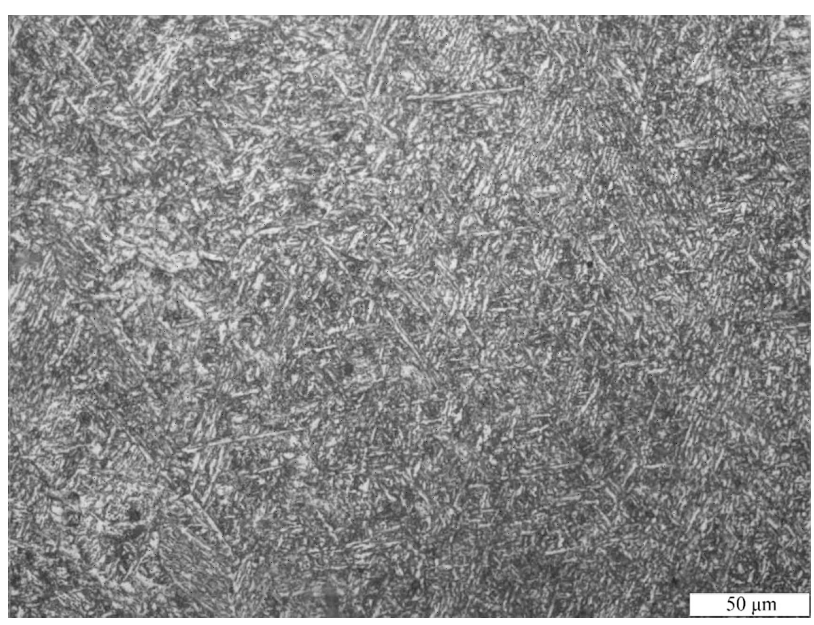

Figure 3: Weld-metal microstructure with predominantly acicular ferrite (sample 21)

Slika 3: Mikrostruktura zvara s prevladujočim acikularnim feritom (vzorec 21) the results of the area fraction of the acicular ferrite and the inclusion diameter no direct dependence could be observed.

Table 4: Microstructure analysis - area fraction of acicular ferrite and non-metallic inclusions

Tabela 4: Analiza mikrostrukture - delež površine acikularnega ferita in nekovinskih vključkov

\begin{tabular}{|c|c|c|}
\hline Sample & $\begin{array}{c}\text { Area fraction of } \\
\text { acicular ferrite, } \%\end{array}$ & $\begin{array}{c}\text { Area fraction of } \\
\text { non-metallic inclusions, \% }\end{array}$ \\
\hline 17 & 68.2 & 1.6 \\
\hline 18 & 60.2 & 1.3 \\
\hline 19 & 72.3 & 1.9 \\
\hline 20 & 62.5 & 1.4 \\
\hline 21 & 74.9 & 2.1 \\
\hline 22 & 66.7 & 1.6 \\
\hline
\end{tabular}

\section{DISCUSSION}

Among other steel deoxidants, $\mathrm{Al}$ is the most commonly used alloying element added for fully killed steel. Therefore, the simple $\mathrm{Al}_{2} \mathrm{O}_{3}$ oxides are often found in different steel grades, but are not considered to be an effective nucleant for AF. But, in steels containing Mn and which have been deoxidized by $\mathrm{Al}$, more complex manganese-oxide inclusion evolve, which then become effective nucleation sites for $\mathrm{AF}^{7}$ Unlike simple Al-oxides, various Ti-oxides are very efficient nuclei for the formation of AF.

Some of the complex oxides can also nucleate AF. More specifically, the observed aluminium-manganese silicates nucleate AF. Their effectiveness can be explained with their highest thermal expansion difference from iron (in comparison with other observed inclusions) resulting in the largest thermal stresses. ${ }^{7}$ Among the observed inclusions, in addition to oxides, some sulphides (MnS) were also found. Pure MnS inclusions, unlike some oxides, are not active nucleants for $\mathrm{AF}$, because they are incoherent in austenite. ${ }^{15}$ Complex oxy-sulphides and multi-phase inclusions observed in analysed specimens are very often stated as nucleants for AF. The factors that positively influence the nucleation of AF are: low mismatch strain between the inclusions and ferrite; positive thermal strains in the surrounding matrix (due to large difference in thermal coefficients for inclusion and matrix) and the formation of Mn-depleted zone in the matrix near the MnS inclusion. Because simple inclusions affect the nucleation of the AF with only one of the mentioned factors, they present less active nucleants for AF compared to the complex inclusions. According to ${ }^{16}$, inclusions consist of an oxide core, which is formed during the primary deoxidation stage. The chemical composition of deoxidation products can vary within wide limits, depending on the relative activities of aluminium, titanium, silicone, manganese and oxygen in the weld metal. Except for the $\mathrm{MnS}$ spotted in the observed inclusions in the experiment, the surface of the oxides can be partially covered by TiN. 
The precipitation of these phases occurs after the completion of the weld-metal deoxidation, probably during solidification, where the reactions are favoured by solute enrichment in the interdendritic liquid.

Regarding the frequency of the occurrence of the observed inclusions, it can be concluded that a smaller amount of inclusions appeared in the samples welded with the CBT metal-transfer mode, resulting in a microstructure with a smaller area fraction of acicular ferrite. The larger acicular ferrite content in the weld metal welded with the natural metal-transfer mode could be explained by the thermal stresses that occur during the welding. Namely, during CBT welding a smaller heat input is introduced to the metal, resulting in smaller thermal stresses, which negatively influence the nucleation of the acicular ferrite. When welding with a higher heat input (conventional metal transfer mode), because of the large difference in the thermal coefficients for the inclusion and austenite matrix, the nucleation of acicular ferrite is more stimulated. Besides the area fraction of inclusions in the weld metal, which has proven to influence the content of acicular ferrite, the size of the inclusion has also been observed to have a great influence, as can be seen from Table 3 and Table 4 . These results indicate the critical size of the particles for the heterogeneous nucleation of acicular ferrite to be around $1 \mu \mathrm{m}$, which is in accordance with previous investigations of other authors. ${ }^{6,7}$ This is a critical value because of the fact that the energy barrier to heterogeneous nucleation of ferrite at inclusions decreases significantly with an increased inclusion diameter in the range from 0 to $1 \mu \mathrm{m}$. This is due to the increasing of the particle surface area. However, it follows from ${ }^{7}$ that the value of this energy barrier for particles with diameters larger than about 1 $\mu \mathrm{m}$ decreases only slightly with a further increase in the inclusion size. Therefore, it is expected that a further increase of the diameter of the inclusions over $1 \mu \mathrm{m}$ does not result in a greater possibility of ferrite nucleation on an inclusion surface.

\section{CONCLUSIONS}

Based on the results obtained in this study, the following main conclusions can be drawn:

- The diameter of the observed inclusions is in direct correlation with its chemical composition,

- Samples welded with CBT metal-transfer mode resulted in weld metals with a smaller amount of inclusions, resulting in a smaller area fraction of acicular ferrite,

- Samples welded with the globular metal-transfer mode resulted in a larger inclusion size to the one welded with short-circuit, metal-transfer mode.

\section{REFERENCES}

${ }^{1}$ T. Era, A. Ide, T. Uezono, T. Ueyama, Y. Hirata, Controlled bridge transfer (CBT) gas metal arc process for steel sheet joining; Welding International, 27 (2009) 4, 268-273, doi:10.1179/136217109X406965

${ }^{2}$ T. Era, T. Ueyama, M. Brooks, Welding steel sheet with a modified short circuiting process, Welding Journal, 87/12 (2008), 28-33

${ }^{3}$ J. I. Achebo, Complex Behavior of Forces Influencing Molten Weld Metal Flow based on Static Force Balance Theory; Physics Procedia, 25 (2012), 317-324, doi:10.1016/j.phpro.2012.03.090

${ }^{4}$ Y. J. Oh, S. Y. Lee, J. S. Byun, J. H. Shim, Y. W. Cho, Non-metallic inclusions and acicular ferrite in low carbon steel, Materials Transactions, JIM, 40/12 (2000), 1663-1669, doi:10.2320/matertrans 1989.41 .1663

${ }^{5}$ E. V. Morales, R. A. Silva, I. S. Bott, S. Paciornik, Strengthening mechanisms in a pipeline microalloyed steel with a complex microstructure, Materials Science \& Engineering A, 585 (2013), 253-260, doi:10.1016/j.msea.2013.07.060

${ }^{6}$ T. K. Lee, H. J. Kim, B. Y. Kang, S. K. Hwang, Effect of inclusion size on the nucleation of acicular ferrite in welds, ISIJ International, 40 (2000), 1260-1268, doi:10.2355/isijinternational.40.1260

${ }^{7}$ D. S. Sarma, A. V. Karasev, P. G. Jönsson, On the role of nonmetallic inclusions in the nucleation of acicular ferrite in steels, ISIJ International, 49/7 (2009), 1063-1074, doi:10.2355/isijinternational. 49.1063

${ }^{8}$ S. Terashima, H. K. D. H. Bhadeshia, Size distribution of oxides and toughness of steel weld metals, Science and technology of welding and joining, 11/5 (2006), 580-582, doi:10.1179/174329306X120868

${ }^{9}$ H. K. Sung, S. Y. Shin, W. Cha, K. Oh, S. Lee, N. J. Kim, Effects of acicular ferrite on charpy impact properties in heat affected zones of oxide-containing API X80 linepipe steels, Materials science and engineering A 528 (2011), 3350-335, doi:10.1016/j.msea.2011. 01.031

${ }^{10}$ S.S. Babu, H.K.D.H. Bhadeshia, Mechanism of the transition from bainite to acicular ferrite, Material transactions, JIM, 32/8 (1991), 679-688, doi:10.2320/matertrans1989.32.679

${ }^{11}$ M. Jurica, Utjecaj zaštitnoga plina i načina prijenosa metala na svojstva zavarenoga spoja čelika X80, Doktorski rad, Fakultet strojarstva i brodogradnje, (2015), Zagreb

${ }^{12} \mathrm{~J}$. Rykała, T. Pfeifer, Influence of the technological conditions of welding using the MIG/MAG method on metal transfer in the welding arc, Welding International, 28/12 (2014), 931-940, doi:10.1080/09507116.2012.753233

${ }^{13}$ Y. Ogino, Y. Hirata, A. B. Murphy, Numerical simulation of GMAW process using $\mathrm{Ar}$ and an $\mathrm{Ar}-\mathrm{CO}_{2}$ gas mixture, Welding in the World, 60/2 (2016), 345-353, doi:10.1007/s40194-015-0287-3

${ }^{14}$ Y.-R. Wong, S.-F. Ling, An investigation of dynamical metal transfer in GMAW-Effects of argon shielding gas, Journal of Materials Processing Technology, 214/1 (2014), 106-111, doi:10.1016/ j.jmatprotec.2013.08.003

${ }^{15}$ T. Furuhara, J. Yamaguchi, N. Sugita, G. Miyamoto, T. Maki, Nucleation of proeutectoid ferrite on complex precipitates in austenite, ISIJ International, 43/10 (2003), 1630-1639, doi:10.2355/ isijinternational.43.1630

${ }^{16}$ J. E. Ramirez, Characterization of High-Strength Steel Weld Metals: Chemical Composition, Microstructure, and Nonmetallic Inclusions, Welding journal, 87 (2008), 65-75 